\title{
The G20 and the Nigerian Vision 20:2020
}

\author{
Dr. Bitrus Nakah Bature \\ Department Of Economics, University Of Jos, Nigeria.
}

\begin{abstract}
It is all about the 20s. Talking of G20 and the Vision 20:2020, is an interesting aspect of economics that identified 20 as that element that matters in development and Gross Domestic Product (GDP) growth in these cases. It is a natural law of 20s that appears at a global level and at a Nigerian level which interestingly, is an issue that this article tries to analyse. A strong, sustainable and balanced growth, remains the top priority of the G20 as it leads to higher jobs creation and increases the welfare of people across the world. The National Implementation Plan for Nigeria Vision 20:2020 on the other hand, has four thematic areas namely: Physical Infrastructure; Productive Sectors; Human Capital Development and Knowledge-based economy. Part one of this work is the introduction. Part two, the G20. Part three is the vision 20:2020. The part four is the relevance of G20 and vision 20:2020 on the Nigeria economy. While part five forms our summary and conclusion.
\end{abstract}

\section{Introduction}

Nigeria has been working very hard amidst all challenges so as to realise or achieve her vision 20:2020 development plan. The Nigerian rate of development right from independence in 1960 has been a dwindling one. One of the important aim of fighting for, and gaining independence was to ensure self-autonomy and asserting development. But for Nigeria, the story has been that of one regime of challenges to another.

Politically, the British colonialism created Nigeria with diverse peoples and regions in an artificially political entity. The inconsistencies in the British policy reinforced cleavages based on regional animosities by attempting simultaneously to preserve the indigenous cultures and activities of each area and to introduce modern western political and social concepts. The three regions were used to bulldoze the political arrangement through revenue needs and derivation principles of governance as the preponderant force to determine the future of the nation. The politics of revenue allocation guided the revenue sharing by three regions-North, West and East. From agriculture and population in the North, cocoa in the West, to oil in the East, Bature(1995).

Oil changed the mentality of Nigerians by shifting production activities from other sectors to concentrate in the exploitation and development of petroleum resources. This is the circumstance that came to be known as the Dutch disease in Nigeria, Bature(2011). Coussy (1989) explained that in West Africa, the result of the existence of the Dutch disease or its absence is non comparable because we treat neither the concept of the syndrome nor the same happening by the instruments contracted to observe it in the same manner. Various regimes came to pass in Nigeria with different lingering problems of governance. The president Yar'adua/Goodluck regime launched the Vision 20:2020, aimed at making or ensuring that Nigeria become one of the Top 20 most developed countries in the world by the year 2020 .

The G20 on the other hand, is an organisation of the group of 20 most developed economies of the world with the objective of assisting poorer or less developed countries of the world to eradicate hunger, poverty and thereby, putting them on the part of development through financial supports for sustainability.

\section{What is a Vision?}

A vision is the knowledge, as well as the imagination which are needed in planning for the future with a clear and suitable purpose. Developed countries of the world worked very assiduously to get industrialised and be placed among the advance economies of the world. This purpose of this in the case of Nigeria is not different as its aim is to be among the top 20 economies of the world by the year 2020 .

\section{Background Of The Vission 20: 2020 Of The Yar'adua/Goodluck Regime}

Every government often try to renew policy actions that will change the standard of living and life quality of its people particularly at the inception of it's regime. The Yar'adua/Goodluck regime enacted an Economic Transformation Policy for Nigeria popularly known as the 'Vision 20:2020' to ensure that Nigeria does not remained underdeveloped and a continuously impoverished nation. The idea was overwhelmingly welcomed and embraced by the people of Nigeria and her foreign friends who meant well for the country.

Historically, various regimes in Nigeria outlined some action plans or policies to put Nigeria on the part growth and development. Some, somehow successful, others were failures. Some of the policies were meant to bring improvement in particular sector(s) of the economy, and some were designed to affect positively 
the entire economy. For instance, several policies on 'education' by different government or regimes in Nigeria were put in place with the hope to bring positive results. In Agriculture, the stories were those of aggressive actions to turn around the ugly story of declining agricultural output vis-a-vis low revenue from a historically booming sector and a major foreign exchange earner for Nigeria, beginning from the era of the three regions, to the early years of independence. In the same spirit of development, the Yar'adua/Goodluck regime introduced the vision 20:2020 tagged a policy of developing Nigeria to an advanced and industrialized country by the year 2020, having mourned the unfortunate and early demise of the Sani Abacha's Vision 2010, and the Obasanjo's Vision 2015.

\section{The Nigeria Vision 20:2020}

The Vision 20:2020 is an articulation of the long-term intent to launch Nigeria onto a path of sustained social and economic progress and accelerate the emergence of a truly prosperous and united nation. Recognising the enormous human and natural endowments of the nation, the blueprint is an expression of Nigeria's intent to improve the living standards of her citizens and place the country among the Top 20 economies in the world with a minimum Gross Domestic Product(GDP) of \$900billion and a per capita income of not less than $\$ 4000$ per annum. Furthermore, Adeyemi (2011: 27) posits that:

The key goals of the vision that would lead to Nigeria becoming the $20^{\text {th }}$ largest economy in the world include growing the economy from its present value of US\$ 315 billion to US\$900billion, and raising the present per capita income of US\$1, 500 to US\$ 4000).

By the above analysis, and by the year 2020, Nigeria will have a large, strong, diversified, sustainable and competitive economy that will effectively harness the talents and energies of its people and responsibly exploits its natural endowments to guarantee a high standard of living and good quality of life to its citizens. Four dimensions were identified for achieving the vision 20:2020 project in Nigeria. According to the policy, the dimensions are:

1. The social dimension: It requires a peaceful, equitable, harmonious and just society, where every citizens are supported by an educational and healthcare system that caters for all, and sustains a life expectancy of not less than 70 years.

2. An economic dimension: It has to do with a globally competitive economy that is resilient and diversified with a globally competitive manufacturing sector that is lightly integrated and contributes not less than $25 \%$ to the GDP.

3. The institutional dimension: This is a stable and functional democracy where the rights of the citizens to determine their leaders are guaranteed, and adequate infrastructure exist to support a market-friendly and globally competitive business environment.

4. The fourth one is the environmental dimension: This explains the level of environmental consciousness that enables and supports sustainable management of the God-giving natural endowments to ensure equitable representation for the benefit of present and future generation.

The essence of this plan is to transform holistically the Nigerian state. Following the vision's authentic blueprint, Nigerian people set for themselves a stretch target to transform the lives of the average citizens which by implication, the Nigerian economy would be transformed. A comparative per capita Gross National Product (GNP) between Nigeria and some 12 other countries shown below, indicates that had the lowest per capita GNP in 1998 .

How The Vision 20:2020 Can Accelerate Economic Development In Nigeria

There are three strategies for realising the vision 20:2020. The three strategies as obtained in the document are:

1. The creation of a platform for success by urgently and immediately addressing the most debilitating constraints to Nigeria's growth and competitiveness

2. a. Aggressively pursuing a structural transformation from a mono-product economy to a diversified industrialised economy;

b. Investing to transform the Nigerian people into catalysts for growth and national renewal and a lasting source of comparative advantage and;

c. Investing to create an environment that enables the coexistence of growth and development on an enduring and sustainable basis.

3. Developing and deepening the capability of government to consistently translate national strategic intent into action and result by instituting evidence-based decision making in Nigeria's public policy space.

The essence of these strategies is to ensure a successful arrival at a transformed Nigeria by the year 2020. If we take a look at Nigeria in a report prepared by the Economic Commission of Africa countries Ajayi, (2003:10), show that Botswana, South Africa, Mauritius Tunisia and Congo ranked first on performance of 
macroeconomics, poverty reduction and institutional transformation. While on the bottom ladder are Zimbabwe, Chad, Guinea and Nigeria in that order in Africa. We can see that Nigeria's situation was not encouraging at all because it was the last among these group of nations in Africa. But the changing nature or transformation effort now show that the performance has improved and Nigeria now requires an annual GDP growth rate of not less than $13.8 \%$ to achieve the vision 20:2020. This requires a revolutionised action that will provide a pattern of growth rate with the capacity and capability for change. For instance, already, the Nigerian economic growth rate is said to be quite impressive as at the year 2012. The country in 2012, was described as the fastest growing economy in Africa amidst distracting terrorists' attacks that forced the government to go into extra and heavy spending on security. The "Netherland, is presently the $20^{\text {th }}$ largest economy in the world with a GDP of \$642 billion" (Usman 2010). Accordingly, Adeyemi (2011:27) explained that, for the vision20:2020 to be achieved, the key macroeconomic assumptions necessary are:

An average crude oil production of 2.5 million barrels per day, crude oil price at US\$ 60 per barrel, real GDP growth rate of $11 \%$ per annum, single digit inflation of $9 \%$ per annum, nominal exchange rate of 145/US\$, population growth rate of $2.8 \%$ per annum, growth in non-oil exports at $30 \%$ per annum, fiscal deficit at $3 \%$ of GDP per annum, amongst others.

Let us take a look at Nigeria and some of the Macroeconomic strategies and policy thrust that will lead to a successful achievement of the target of the year 2020.eg fiscal policy thrust, public debt policy thrust and monetary policy thrust as well as external sector policy thrust. As for Nigeria, a developing economy indeed, the best thing that she requires is an economic transformation strategy to take it to a stage of advanced industrialised economy. Nigeria has journeyed through some vision plans with different development strategies. Some of these visions includes the Babangida Vision 2000, the Abacha Vision 2010, the NEEDS as the Obasanjo Vision 2015, which is a rolling plan into the vision 20:2020 development strategy. The common thing about these visions is that they were not implemented.

\section{The Implementation Strategy}

The vision 20:2020 was introduced in 2007 by the late Yar'adua's regime as a cardinal goal of attending the seven point agenda. points. By April of the following year, a committee was put in place to develop a document to this effect. The document was to provide a road map for accelerated economic development in Nigeria. Hence, the plan was targeted at the use of plan periods such as 2009-2012 as the first plan period; 2013-2016 as the second plan period and lastly, 2017-2020 to be the third plan period.

The first four years plan period 2009-2012 was meant to achieve the medium-term development plan through evaluation and ensuring the sustainability of some macro-economic variable growth such as the Nigeria GDP. This was to continue with the journey to the 2020 as a year that Nigeria will be expected to achieve her planned dream of being among the 20 industrialised countries of the world.

Development of science and technology as the engine room towards achieving the 20:2020 objective, should be held sacrosanct. It is technology that led(brought) many countries of the world to the industrialized stage even with the absence of any natural or primary resources. Countries such as Japan, China and Korea have succeeded through technology. Nigeria must move away from a consumer of technology to a producer of technology. Our worry is that, in Nigeria, the continuity of a predecessor's policies are never guaranteed. This is a major problem that could affect the vision 20:2020, should a new regime come after president Goodluck Jonathan, and discontinued the already existing policy, thereby, seeing it as a Yar'adua/Jonathan initiative, rather than a Nigeria initiative. Should the vision eventually be stopped midst way, then, will the problem of the lack of continuity be the one to kill this important economic transformation policy.

\section{The G20 Nations And Their Glogbal Actions}

We cannot talk of G20 without mentioning other groups of nations that have similar economic policies across the globe. For instance, we have the G6, G7, G8, G22, G33,etc. To get to the basis of this analysis, we start with the G33 and so on.

\section{The $G 33$}

The G33 are industrialised countries of the world, made up of developed and developing nations. The group was formed in 1999. Though, leading national economies of the world, the G33 did not last long as it was superseded by the G20 late in the same year. The G33 on its on part superseded the G22. The meetings of the G33 like any other one was made up of finance ministers and central bank governors. Their first meeting was actually held in Boun, Germany in the year 1999. The group of these leading economies accordingly, include nations such as:

Argentina, Australia, Belgium, Brazil, Canada, Chile, China, Côte d'Ivoire, Egypt, France, Germany, Hong Kong (autonomous territory), India, Indonesia, Italy, Japan, Malaysia, Mexico, Morocco, Netherlands, 
Poland, Russia, Saudi Arabia, Singapore, South Africa, South Korea, Spain, Sweden, Switzerland, Thailand, Turkey, United Kingdom and the United States of America.

Facing the fact that Nigeria is absent from the above list, even as the largest nation in Africa, calls for concern and encouragement from both its government and the international community, especially the G20 members.

\section{The G22}

The G22 as another group of industrialized nations of the world on the other hand, was made up of G8 countries plus 14 other countries. The G8 are Canada, France, Germany, Italy, Japan, Russia, United Kingdom and United States. While the other 14 nations are: Argentina, Australia, Brazil, China, Hong Kong, India, Indonesia, Malaysia, Mexico, Poland, Singapore, South Africa, South Korea and Thailand.

The G22 was also referred to as the Willard Group formed in 1997. The purpose of their formation was to convene a meeting of the finance ministers and central bank governors who were to make proposals on global financial system reform in the world. Their first meeting was held in Washington D.C. which enabled them to consider the suitability of the international financial system and capital markets. Of course, it was superseded by the G33 in 1999 and then, the G33 was equally superseded by the G20.

From the G20, we can see that some countries which were members of the G22 could not be members of the G20. These countries include Singapore, Hong Kong, Malaysia and Thailand. On the other hand, European Union, Turkey, and Saudi Arabia are the other members which were not members of the G22 that became members of the G20 later that same year. Poland was a member of the G22, but it only became a represented country in the G20 by the European Union seat. Others include the G7 and the G8.

\section{The G7:}

The G7started in 1975. Initially, it was G6, i.e. France, Germany, Italy, Japan, United Kingdom and United States. Their purpose was the same as to deal with global financial needs. The coming in of Canada, made it the G7. These are countries that formed $50.4 \%$ of the global nominal GDP and $39.3 \%$ of the global GDP(PPP). Their major concern was to discuss economic policies that affects the globe.

\section{The $G 8$}

The G8 is made up of countries such as Canada, France, Germany, Italy, Japan, Russia, United Kingdom and the United State of America. Their 2008 meeting was attended by their finance ministers as follows: Canada (Jim Flaherty), France(Christine Lagarde, the present World Bank president), Germany (Peer Steinbrueck), Italy (Tommaso Padoa-Schioppa), United State (Henry Paulson), Japan (Fukushiro Nukaga), United Kingdom(Alistair Darling), while, the European group by Jean-Claude Juncker.

\section{The G20}

The G20 as a group of industrialised nations resolved that they would promote growth and create jobs around the world. The fact is that, global economic recovery continued to face difficult challenges, which ranges from external, fiscal and financial imbalances, still prevalent in our society at large.

Among all these groups of economic relevance in the world, Nigeria is constantly missing. This explains the acceptability of a well thought policy by the Yar'adua/Jonathan. Nigeria as a giant of Africa, should be amongst these economic groups that matter in global economic policies, giving all the advantages and available natural and human resources endowed the nation.

The G20 at its Mexico 2012 summit progress report of the development working group, vowed to addressing the most pressing challenges of development and poverty reduction, including the fulfilment of the United Nation Millennium Development Goals.ie promoting sustainable development and eradicating poverty by ensuring sustainable economic growth and decent job creation which has been enshrined in the Nigeria vision 20:2020. The G20 had argued in the report that,

In 2012, approximately 925million people in the world remain undernourished. With world population estimated to grow to 9.3 billion by 2050 , food production needs to grow by $50-70 \%$.

The challenges include increasing food demand structural poverty; scarce resources;

modest agricultural productivity; smallholder farmers needs; climate change;

commodity price volatility; under-nutrition (including stunting), especially for

mother and children; gender inequality including women's limited access to land

and capital; losses across the value-chain; achieving PPP for low income countries;

enhancing rural job creation etc.

In the same, (Akin 2012:6) explained that 'a combination of jobless growth, rising incidence of poverty and income inequality, and declining economic prosperity, has contributed significantly to the emergence of a more polarized economic, social and political space with significant adverse social and economic consequences. 


\section{Some G20 Commitments to the World}

At the G20 Mexico summit, 2012 for instance, specific goals were set with the intention to:

1. Reduce the fiscal cost of subsidies and free resources for infrastructure investment, as well as to improve the distribution of income by channelling subsidies exclusively to lower-income households.

2. Increase the financing of both infrastructure and private sector real investment in order to augment the rate of growth of potential output.

3. Increase banking sector soundness and resilience by upgrading the regulatory framework to the best international risk management practices.

4. Strengthen financial stability.

5. Bolster economic development.

6. Protect consumers of financial services and foster competition in the banking system.

7. Augment energy supply and increase the share of green technologies in electricity generation.

8. Reduce absolute poverty and improve the distribution of income.

9. Drive investment and provide new job opportunities in clean energy sources and support long-term competitiveness as the world moves to a carbon constrained economy.

10. Invest in high-quality infrastructure projects that will expand capacity and boost productivity.

11. Encourage greater workforce participation by removing disincentives to participation for dependent spouses and other dependents.

12. Reduce labour market barriers to entry and encourage greater workforce participation by boosting capacity and enhancing skills.

13. Counter risks to financial and macro economic stability associated with strong and volatile capital inflows and rapid credit expansion.

14. Enhance competitiveness by diversifying exports and to facilitate internationalization of companies.

15. Ensure the suitability of our social programs and physical position over the longer term.

16. Reduce systemic risk and improve market efficiency, transparency and integrity.

17. To promote the stability of the financial system.

18. Create the right environment that would attract investments and promote productivity, growth and economic competitiveness as well as supporting free and open market.

19. Promote productivity and Enovation, as well as creating the right environment to attract investments.

20. Optimise monetary policy target system, improve the transmission mechanism and environment of monetary policy.

21. Increase physical sustainability through mid-term fiscal consolidation.

22. Ensure that short-term public finance objectives are met by increasing public revenues as needed while reducing inequalities and avoiding diverse effect on growth.

23. Secure mid-term public finances objectives by defining governance rules.

24. Put emphasis on growth-friendly composition, while prioritizing public spending towards investments in human capital, research and innovation.

25. Increase growth potential and employment.

26. Prudent fiscal management to provide conducive environment for investment without undermining growth.

27. Help minimise external imbalances.

28. Improve efficiency and reduce distortions in tax collection, and to reduce compliance cost.

29. Increase spending efficiency and support stronger and more balanced growth across regions.

30. Provide legal foundation for crisis management, and to secure financial system that would support macroeconomic stability as a fundamental for growth.

31. Improve business climate and facilitate trade.

32. Speed up the infrastructure development, mainly by regulatory measures to facilitate project financing.

33. Implement the internationally agreed financial regulatory reforms.

34. Guarantee work opportunities for the vulnerable and disadvantaged.

35. Achieve price stability, while safeguarding financial stability.

36. To prevent a sharp drop or even contraction in the pace of economic growth.

\section{The Relevance Of G20 And Vision 20:2020 On The Nigeria Economy}

The economic planning process in Nigeria had serious documentation problem. The first plan was under the colonial rule in 1946. It was a ten year plan tagged "Development and Welfare 1946-1955". The plan was designed to improve economic and social infrastructure, and to create favourable atmosphere for foreign investment (Adeyemi 2011:19). Even though the story of development in Nigeria has not been too positive, recent time development as found in most of the economic indicators shows dramatic changes and/or improvement in recent years. 
Table 1. Real GDP of Nigeria and some Economies compared in 2010.

\section{World}

Sub-sahara Africa

Netherlands

Turkey

Indonesia

Belgium

Sweden

South Africa

Egypt

Nigeria

Source: World Bank Development Indicator, International Financial Statistics of the International Monetary Fund.

\section{US\$ 'Billion}

$50,158.97$

802.52

621.22

395.38

393.86

389.00

381.51

255.27

131.89

124.92

Table 2. Sectoral Growth Performance (\%): 2009 \& 2010.

$\begin{array}{lccc}\text { Key Sectors } & \text { Baseline } & \text { Actual } & \text { Target } \\ \text { Year } & \mathbf{2 0 0 9} & 2010 & \mathbf{2 0 1 1} \\ \text { Oil } & \mathbf{0 . 4 5} & 4.98 & \mathbf{2 . 6 0} \\ \text { Non-Oil } & \mathbf{8 . 3 2} & \mathbf{8 . 4 3} & \mathbf{1 1 . 0 0} \\ \text { Agriculture } & 5.88 & 5.64 & 6.60 \\ \text { Manufacturing } & 7.85 & 7.64 & \mathbf{2 2 . 3} \\ \text { Finance \& Insurance } & 4.01 & 3.95 & 4.50 \\ \text { Building, Construction \& Real Estate } & 11.49 & 11.41 & \mathbf{3 4 . 0 0} \\ \text { Utilities } & 3.23 & 3.32 & \mathbf{1 7 . 4 0} \\ \text { Transport } & 6.83 & 6.72 & 7.20 \\ \text { Wholesale \& Retail Trade } & 11.45 & 11.19 & \mathbf{1 0 . 8 0}\end{array}$

Source: National Bureau of Statistics and National Planning Commission

The situation as seen on the two tables above shows a weak and discouraging results. But looking at the other two tables below, indicates a dramatic changes as it concerns the Nigerian economy.

TABLE 3: ECOWAS Real GDP Growth (\%)

\begin{tabular}{|l|l|l|l|l|l|}
\hline COUNTRY/YEAR & $\mathbf{2 0 0 7}$ & $\mathbf{2 0 0 8}$ & $\mathbf{2 0 0 9}$ & $\mathbf{2 0 1 0}$ & $\mathbf{2 0 1 1}$ \\
\hline AFRICA & 6.40 & 5.60 & 2.50 & 4.50 & 5.20 \\
\hline ECOWAS & 5.70 & 5.60 & 5.60 & 6.80 & 6.50 \\
\hline UEMOA & 3.20 & 3.90 & 3.10 & 3.90 & 4.40 \\
\hline Benin & 4.60 & 5.00 & 2.70 & 2.90 & 3.50 \\
\hline Burkina Faso & 3.60 & 5.20 & 3.20 & 5.20 & 5.50 \\
\hline Code d'Ivoire & 1.60 & 2.30 & 3.80 & 3.00 & 4.00 \\
\hline Guinea Bissau & 3.20 & 3.20 & 3.00 & 3.50 & 4.30 \\
\hline Mali & 4.30 & 5.00 & 4.50 & 4.50 & 6.00 \\
\hline Niger & 3.40 & 9.60 & -0.90 & 7.50 & 3.20 \\
\hline Senegal & 4.90 & 3.20 & 2.20 & 4.00 & 4.40 \\
\hline Togo & 2.10 & 2.40 & 3.20 & 3.40 & 3.90 \\
\hline WAMZ & 6.40 & 6.10 & 6.40 & 7.60 & 7.10 \\
\hline Gambia & 6.00 & 6.10 & 4.60 & 5.50 & 5.10 \\
\hline Ghana & 6.50 & 8.40 & 4.70 & 6.60 & 6.50 \\
\hline Guinea & 1.80 & 4.90 & -0.30 & 1.90 & 4.00 \\
\hline Liberia & 3.20 & 3.50 & 3.60 & 3.70 & 3.90 \\
\hline Nigeria & 6.50 & 6.00 & 6.70 & 7.90 & 7.30 \\
\hline S/Leone & 6.00 & 4.00 & 3.20 & 5.00 & 4.90 \\
\hline Other(Capeverde) & 8.60 & 6.10 & 4.00 & 5.60 & 4.40 \\
\hline
\end{tabular}

Source: WAMA, June 2012

\section{*The figures for Liberia are estimates}

The Nigerian economy is seen as a fast growing one. Infact, it has been described as the third fastest growing economy in the world in recent time. Dozie, (2012:17) described the Nigerian economy as being on the fast lane of growth. Even before then, a year earlier, one Richard Sandock of the World Bank argued that the Nigerian economy is the $4^{\text {th }}$ world's fastest growing economy which took over from Russia and South Africa. This position was a confirmation of Mr. Henry Bellingham of the United Kingdom's view under Secretary of state for Africa and Overseas Territories at an investment forum held in London that rated Nigeria as the $4^{\text {th }}$ fastest growing economy in the world. 
Although, other school of thought maintain their doubts on this growth rate especially with the activities of Boko Haram in the northern states which is believed be diverting as much as $2 \%$ of the output of the country's economy, added to the non-diversification, declining power statues, and poor manufacturing sector of the economy. The argument still stand that with the will power from most Nigerians, the dream will not be a mirage.

\section{The G20 Toronto Summit Declaration: The Benefits to Developing Economies Like Nigeria}

As an International Economic Cooperation, the summit was to address global economic crisis by ensuring a full return to growth with quality jobs, reforms, and to strengthen the financial system, as well as to create a strong and sustainable balanced global growth.

Countries with serious fiscal challenges need to accelerate the pace of consolidation. The G20 highest priority is safeguarding and strengthening recovery and strong foundation for sustainable and balanced growth. By this, the policy actions must be consistent in order to achieve higher global output for better diversification of the economy, millions of jobs to eradicate unemployment, lift more people out of poverty, and significantly reduce the global imbalances. This is because a global growth will improve the lives of citizens in the poorer countries of the world. The essence of this action is to create jobs and achieve stronger economics and to sustain a more balanced growth and price stability. Again, to achieve exchange rate flexibility in some emerging markets of the world. By this, the G20 members must equally pursue strong structural reforms and growth prospects with better economics surpluses by focussing on domestic sources for growth.

On financial sector reform, the G20 members aim is to build a financial system that serves the need of the world economy by reducing moral hazards and limiting the risk through support for strong and stable economic growth by acting together with positive impact on emerging economies. For this to be a success, there must be greater attention to reposition all sectors of the economy, if Nigeria is to be among the top 20 economies of the world in the year 2020. Infact, it has been postulated by WPC that Nigeria will became the $13^{\text {th }}$ most developed country in the world by the year 2050 .

\section{Summary And Conclusion.}

Following the growth rate speed, the performance of the Nigerian economy as demonstrated in recent time is convincing enough that the country could advance to the dream of the year 2020 of the 20 most developed and industrialised nation. Many of the emerging economies such Brazil, India, Singapore have to insist on parts of growth by ensuring levels of good governance and patriotism.

Nigeria can easily achieve the development objectives set by the Vision 20:2020 transformation target agenda through careful diversification of the numerous sectors of the economy. The concentration of development attention on a single sector (Oil), over the years has not been a good development strategy for the nation. Nigeria is a country with vast land made up of 934000square kilometres. Apart from a population of over 170million people, Nigeria is blessed with a variety of primary resources and other minerals, both oil and non oil such as the abundant deposits of Solid mineral resources. A sure way to development is by harnessing the resources and channelling the proceeds towards the development of other sectors of the economy. It is only by doing this that output in the economy will change and increase positively to transform the economy.

The concept of change in this case is a necessary condition to the Nigeria's objective. There must be a change in attitudes particularly by eliminating corruption in the society, and a change in the mind sets especially in the way they think about their culture, religion, and education. It will involve a lot energy in workshops, seminars, advocacies, teaching, town hall committees and the introduction of new concepts and ideas into the educational curriculum. All bodies, organisations, professional associations, corporate bodies, financial institutions, labour unions must all rise to the task of brainstorming the way forward for Nigeria to achieve this noble objective of advancement. Nigeria must equally work very hard to better the statues and life quality of its youths so as to have a healthy youths with the capacity and capability to propel the nation towards attaining the vision 20:2020 transformation agenda.

Nigeria's foreign policy must not also be weakened, rather it should be strengthened. The relationship between Nigeria and her foreign friends should be widely positive and should waxed stronger and stronger everyday, every time and every year. The unnecessary domestic distractions should not attract so much attention as to result in the weakening of our external relations which are vital to this transformation programme.

While striving at the Nigerian angle for development and advancement, the G20 summits and document of development must also be of interest, to the policy makers. My understanding of the G20 activities is that they are out to shape the world positively. They are also prepared to use their resources to fight poverty, corruption, hunger, diseases and to reduce the quests for wars. Thus, the G20 is an important world body Nigeria should relate with very well and all the time. Mabogunje, (1995:1) explained that:

Development is about wealth creation; the second is that every society succeeds best

in this endeavour when it adopts and transforms its own institutions, its mores and 
the general attitude of its people towards the achievement of this goal.

If by the year 20:2020 we are able to construct good roads Lagos-Abuja-Kano-Sokoto, as well as Lagos to PortHarcourt, and then PortHarcourt to Maiduguri linking up with most of the central state. The economy and industrialisation activities must definitely boom. When they are able to evolve changes in our culture, political change will take place. If all other ministries and parastatals began to experience such positive changes especially in research development, technology, ICT, agriculture, Oil and gas, health, tourism and raw material development, we shall see that we are sitting on a crazy economy.

\section{References}

[1]. Adeyemi, K. S. (2011). Governace, Budgeting and Planning in the Economic Transformation of Nigeria. Presidential address delivered at the $52^{\text {nd }}$ Annual Conference of the Nigerian Economic Society, held at the African Leadership Development Centre, Covenant University, Ota, Ogun State. $11^{\text {th }}-15^{\text {th }}$ September, 2011.

[2]. Ajayi, S. I. (2003). Nigeria and the Political Economy of Development: The dreams, the Myth and the Reality. Presidential Address to the $44^{\text {th }}$ Annual Conference of the Nigerian Economic Society, held at the University of Ibadan Conference Centre, Ibadan, 27-29 August 2003.

[3]. Akim, I. (2012). The Nigerian economy: Some Reflections. A presidential address delivered at the $53^{\text {rd }}$ Annual Conference of the Nigerian Economic Society, held at Nicon Luxury Hotel, Abuja $27^{\text {th }}-30^{\text {th }}$ August 2012.

[4]. Acemoglu, D. andRobinson, J. (2000), "Political Lossers as A Barrier to Economic Development"' Political Economy, Governace and Development, Vol.90, No.2,pp126-130.

[5]. Bature, N.B.(1995). "Politics of Revenue Allocation in Nigeria: A perspective Analysis" in Akor, M.E (ed) Readings in Contemporary Economic Issues. Mono Expression, Jos.

[6]. Bature, N.B. (2011). An evaluation of the impact of the Dutch Disease on the Nigerian economy (1970-2006). Ph.D thesis University Of Jos, Nigeria.

[7]. Bardhan, P. (1999). Institutions, Governance and Political Economy of Development: Some Reflections. Journal of African Economies. Vol.8, Suplement 1.pp.149-167

[8]. CBN. (2011). Monetary Policy Review $3^{\text {rd }}$ Edition, Volume 1,No 3. August, 2011

[9]. Corden, W. (1984). Booming sector and Dutch Disease Economics: Survey and Consolation. Oxford Econ.. Papers 36, 3:pp.359380 .

[10]. Coussy, J. (1989). "Le conservatisme de la politique économie du Cameroon depuis l'indépendance : Origines, rationalité et conséquences", in Geschière p. et Koening, (ed).Pp, 64-66.

[11]. Dozie, O.(2012). Nigeria now world's $3^{\text {rd }}$ fastest growing economy? The Mirror. Friday, April $20,2012$.

[12]. G20 Mexico summit, 2012 Report.

[13]. Hajnal, Peter I. (1999). The G8 system and G20: Evolution, Role and Documentation, pp.30. at Google Books.http://web.archive.org/web/19981212012854/http://birmingham.g8summit.gov.uk/. Retrieved 2011-05-21.

[14]. Kayode, M.O. (2004). Towards a re-birth of Nigeria's Economic development. Fifth Annual Public Lecture of the Nigerian Economic Society, delivered at Nicon Hilton Hotel, Abuja, $24^{\text {th }}$ Febuary 2004.

[15]. Mabogunje, A.L. (1995). A Concept of Development. Ibadan, Development Policy Centre. (working Paper)

[16]. National Planning Commission: Nigeria Vision 2020, December 2009.

[17]. Usman, I. (2001). "Some Reflections on Budget Implementation in Nigeria," Speaking Notes at an EFCC Budget Seminar in Abuja, August 9. 